\title{
Factors Affecting Self-Regulation of Students in Indonesian Traditional Muslim Schools
}

\author{
Agus Fawait ${ }^{1}$, Safaruddin ${ }^{2}$ \\ 1 STAI At-Taqwa Bondowoso, Bondowoso, Indonesia \\ 2IAIM Sinjai, Sinjai, Indonesia
}

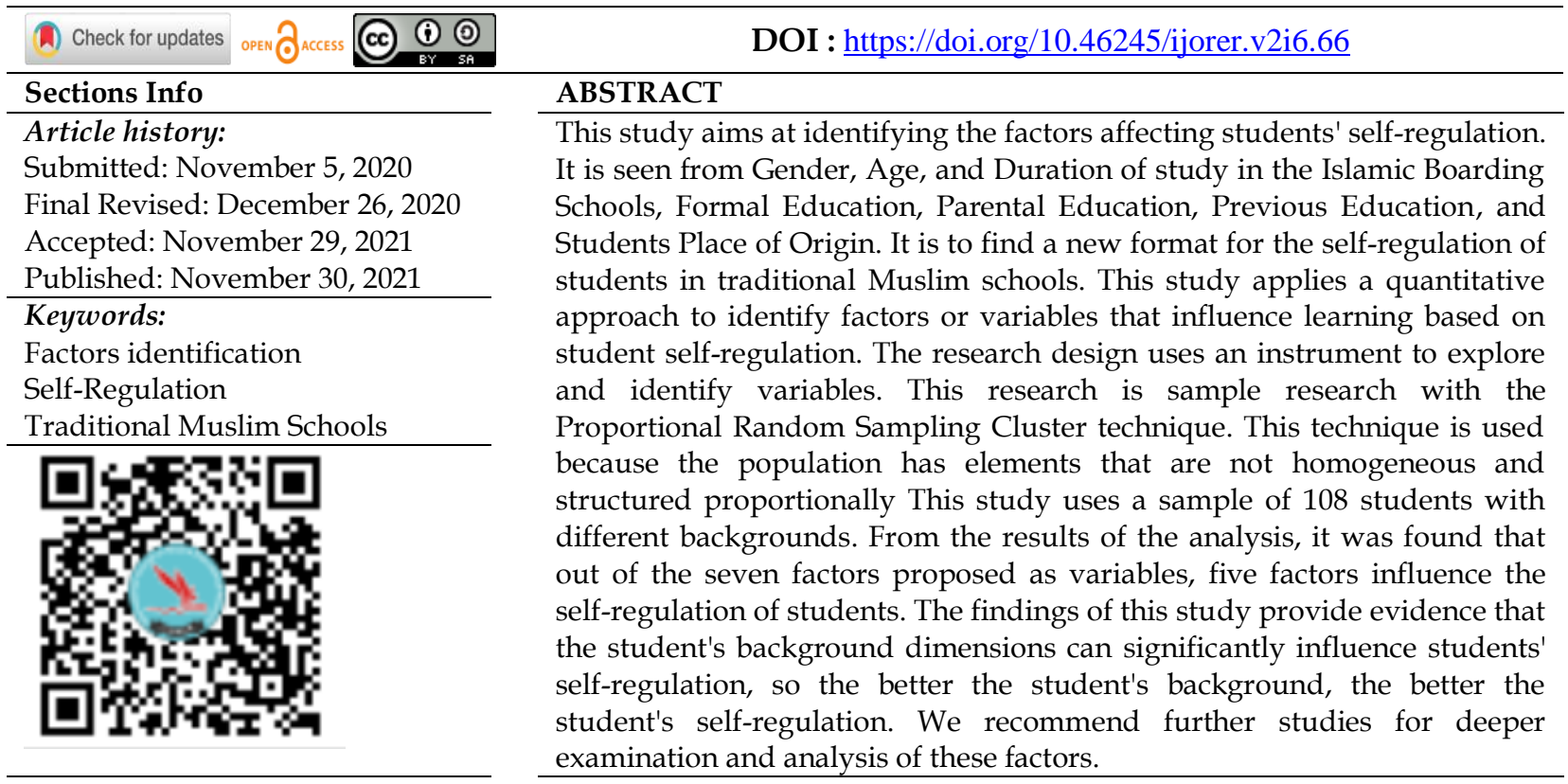

\section{INTRODUCTION}

Islamic boarding schools as institutions focusing on religious education, in particular, emphasize the understanding of yellow books. Islamic boarding schools have pedagogical concepts that integrate science with the art of teaching and have various methods that can model the education system in the Indonesian archipelago (Ma'arif, 2018). Fatmawati (2018) notes that Islamic boarding schools apply varied learning models for the mastery of religious knowledge and student personality education oriented to the development of good behavior, values, and norm. It follows the opinion of (Winarko, 2007) stating that learning in boarding schools can help students develop more meaningful knowledge than individual learning in public schools. Thus the existence of learning technology in Islamic Boarding Schools takes an important role in developing a better understanding (Suardi \& Hamid, 2013). The existence is supported by a good learning environment that supports the achievement of student goals.

The high demand for learning, as well as the extent of the target of understanding yellow books, and the density of learning activities both in traditional schools and in dormitories, requires students always to be able to manage themselves well so that the target of learning can be achieved optimally (Fawait, 2016). Thus Roslan et al. (2014) argue that self-regulation for students of Islamic boarding schools needs to be applied to improve the yellow book thinking reasoning containing Arabic and literature, interpretation of the Qur'an, hadith, fiqh, theological discussion, Sufism, and history. 
This fact requires students to extend the program outside the classroom by creating a learning environment through dormitory activities (Yusuf \& Suardi, 2015), and developing an environment to support learning process in boarding schools (Suardi, 2015) and the presence of external stimulus support (Suardi \& Hamid, 2013).

Several factors influence the success of self-regulation, i.e., self-efficacy, motivation, and goals (Cobb, 2003). While in this study, these factors were developed based on these qualifications; First Gender, in the previous study, it was found that women had better achievements than men and were more likely to win honors (Yates, Smith, James, \& Ferguson, 2009). Second, Age. Age was a predictor of student achievement at a college in southern Texas (Amro \& Kupczynski, 2015), and there were differences in academic abilities between age groups (Jabor, 2011). The third is the length of study in Islamic boarding schools, and this is supported by the results of research that show the duration of staying in a dormitory improves better performance (Araujo \& Murray, 2010) because it affects student retention. Fourth, Formal Education is based on the results of a study that explores academic achievement regarding the two main components of independent learning for students in primary and secondary schools, the results of which the correlations are significantly different (Dent \& Koenka, 2016). Self-regulation does not show a significant difference in school level (Ergen \& Kanadli, 2017). Fifth, Parental Education is based on a study that showed self-regulation was found to correlate with enrollment in postsecondary remedial courses. Parental education was a significant mediating factor (Orange \& Hodges, 2015). It affects children's education (Kainuwa \& Yusuf, 2013). In Germany, parents educational background is a significant predictor (Biedinger, 2011). Sixth, the previous educational factor is based on the study's findings that students from single-sex secondary schools worked significantly better than their peers (I.O. Okere, 2013). The previous educational experience contributes to self-regulation in learning (Phan, 2011) and to carrying out activities (Irdianto \& Putra, 2016). Seventh, the place of students' origin is also one of the factors to be measured, it is supported by the results of research that showed students from rural areas do not experience lagging in academic performance (Alokan \& Arijesuyo, 2013), they are even significantly better at achieving average and interest scores than in the urban schools (Ajai, 2013).

This study aims to develop Islamic boarding school learning from a teacher-centered paradigm to a student-centered one that emphasizes self-regulation in learning. Because pesantren as an unpretentious institution is often labeled as camouflage for life because it always deals with the issue of the afterlife (Fawait, 2017). SRL needs to be applied to help students develop thinking skills (Yildirim \& Ozkahraman, 2011) and provide skills to students (Fawait, 2013). Students can experience an exciting learning process (Reigeluth, 2009, because there must be an interaction between the learning approach and the increase of SRL (Aminah, 2018), make students more active in the process of obtaining knowledge directly so that students are easier to remember and interpret (Jannah et al., 2020). Students have strong motivation to engage in interpersonal communication (Ningsih et al., 2018), and can harmonize general perceptions of the learning process (Järvelä et al., 2016), which influences the flow of discussion (Ucan \& Webb, 2015), and it depends on the level of self-efficacy (Manafe et al., 2016). Where self-regulation occurs as a strategic activity that plays a role in collaborative learning (Isohätälä et al., 2017), and helps them to think critically in evaluating themselves (Ratminingsih et al., 2017), influences Metacognition awareness and cognitive abilities 
(Pantiwati, 2017), improving student learning outcomes (Kastur et al., 2020), so that the focus of student learning shifts from the stage of understanding the task to monitoring activities (Järvelä et al., 2016).

\section{RESEARCH METHOD}

\section{Research Design}

This study applies a quantitative approach to identify factors or variables that influence learning based on student self-regulation. The research design uses an instrument to explore and identify variables. The variables consist of seven independent variables namely Gender $\left(X_{1}\right)$, Age $\left(X_{2}\right)$, Length of study in Islamic Boarding Schools $\left(X_{3}\right)$, Formal Education $\left(X_{4}\right)$, Parental Education $\left(X_{5}\right)$, Previous Education $\left(X_{6}\right)$ and Place of Students' Origin $\left(X_{7}\right)$. While the dependent variable is the students' self-regulation $(Y)$.

\section{Population and Sample}

This research is sample research with the Proportional Random Sampling Cluster technique. This technique is used because the population has elements that are not homogeneous and structured proportionally both in terms of sex $\left(X_{1}\right)$, age $\left(X_{2}\right)$, length of study in boarding schools $\left(X_{3}\right)$, formal education $\left(X_{4}\right)$, parental education $\left(X_{5}\right)$, previous education $\left(X_{6}\right)$ and the students' place of origin $\left(X_{7}\right)$. With a sample of 108 students.

Table 1. Demographic of participants.

\begin{tabular}{ccc}
\hline Variables & Category & Percentage \\
\hline \multirow{2}{*}{ Gender } & Men & $46 \%$ \\
& Women & $54 \%$ \\
& 13 Year Old & $2 \%$ \\
& 14 Year Old & $8 \%$ \\
& 15 Year Old & $25 \%$ \\
& 16 Year Old & $8 \%$ \\
Age & 17 Year Old & $21 \%$ \\
& 18 Year Old & $13 \%$ \\
& 19 Year Old & $7 \%$ \\
& 20 Year Old & $8 \%$ \\
& 21 Year Old & $4 \%$ \\
& 22 Year Old & $2 \%$ \\
& 23 Year Old & $2 \%$ \\
& 24 Year Old & $1 \%$ \\
& 26 Year Old & $1 \%$ \\
& 1 Year & $1 \%$ \\
& 2 Year & $30 \%$ \\
& 3 Year & $34 \%$ \\
& 4 Year & $21 \%$ \\
& 5 Year & $8 \%$ \\
& 6 Year & $2 \%$ \\
& 7 Year & $3 \%$ \\
& 8 Year & $1 \%$ \\
& Middle School & $46 \%$ \\
& High Schoool & $34 \%$ \\
& University & $20 \%$ \\
& Primary School & $2 \%$ \\
& Middle School & $21 \%$ \\
& High Schoool & $52 \%$ \\
& University & $25 \%$ \\
\hline
\end{tabular}




\begin{tabular}{ccc}
\hline Variables & Category & Percentage \\
\hline \multirow{2}{*}{ Previous Education } & Public School & $39 \%$ \\
& Islamic School & $61 \%$ \\
\multirow{2}{*}{ Students' Place of Origin } & Rural Areas & $71 \%$ \\
& Suburbs & $24 \%$ \\
& Urban Areas & $5 \%$ \\
\hline
\end{tabular}

\section{Instruments}

This research is measured using research instruments developed by (Vrieling, Bastiaens, \& Stijnen, 2013), namely Self Regulated Learning Opportunities Questionnaire (SRLOQ). This questionnaire contains 56 statements consisting of; 4 statements regarding Planning consisting of a) Goal settings totaling nine questions, b) Metacognitive knowledge activation totaling two questions, c) Task value activation totaling two questions, d) Time management totaling four questions. 1 question about Monitoring of the learning process which consists of Metacognitive awareness and monitoring of cognition which consists of 6 questions. 2 questions about Zone of proximal development which consist of a) Prior knowledge activation which consists of 10 questions, b) Perceptions of task difficulty which are two questions. Three questions about Coaching/judging consist of a) Metacognitive awareness and monitoring of cognition which amounts to 8 questions, b) Judgments totaling six questions, c) Attributions which amount to 2 questions. And 1 question about Collaboration, which consists of 5 questions. The ordinal scale is used in preparing the questionnaires. It allows respondents to express their feelings. The answers to each question are numbers 1 to 5 in each category. The answers to each question are strongly agree, agree, no comment, disagree, and strongly disagree. The number of response options used is only 1 to 5, arguing that the result is too rough if the response is too little. Conversely, if there are too many response choices, respondents are feared that it will be difficult to distinguish between one response and another response choice. In addition, this study also uses the Nominal Scale, and the nominal measurement scale is used to classify individuals from Gender, Age, Length of study in Islamic Boarding Schools, Formal Education, Parental Education, Previous Education, and Students' place of Origin.

\section{Data Analysis}

Based on the research objectives, the data analysis used multiple analysis methods, namely the t-test and ANOVA. This method is to see the influence of independent variables on the dependent variable in the study. The independent variables are Gender $\left(X_{1}\right)$, Age $\left(X_{2}\right)$, Length of study in Islamic Boarding Schools $\left(X_{3}\right)$, Formal Education $\left(X_{4}\right)$, Parental Education $\left(X_{5}\right)$, Previous Education $\left(X_{6}\right)$, and the Student's Place of Origin $\left(X_{7}\right)$. At the same time, the dependent variable is the Student's Self-Regulation (Y). The data analysis technique is done with the SPSS computer program.

\section{RESULTS AND DISCUSSION}

The findings study is to measure each of the students' background variables by students' self-regulations. Based on the results of SPSS analysis, the measurement results are found as Table 2 . 
Table 2. Gender.

\begin{tabular}{lccccccccc}
\hline \multicolumn{1}{c}{ SRL } & F & Sig. & T & Df & $\begin{array}{c}\text { Sig. (2- } \\
\text { tailed) }\end{array}$ & $\begin{array}{c}\text { Mean } \\
\text { Difference }\end{array}$ & $\begin{array}{c}\text { Std. Error } \\
\text { Difference }\end{array}$ & $\begin{array}{c}\text { 95\% Confidence } \\
\text { Interval of the } \\
\text { Difference } \\
\text { Lower }\end{array}$ & Upper \\
\hline $\begin{array}{l}\text { Equal variances } \\
\text { assumed }\end{array}$ & 4.550 & .035 & -2.352 & 106 & .021 & -3.137 & 1.334 & -5.780 & -.493 \\
$\begin{array}{l}\text { Equal variances } \\
\text { not assumed }\end{array}$ & & & -2.301 & 88.881 & .024 & -3.137 & 1.363 & -5.846 & -.428 \\
\hline
\end{tabular}

Table 2 shows that the significance is $0.035<0.05$ then Ho is rejected, and Ha is accepted. It means that gender influences the self-regulation of students.

Tabel 3. Age level on the self-regulation of students.

\begin{tabular}{lrrrrr}
\hline \multicolumn{1}{c}{ Source } & Sum of Squares & df & Mean Square & F & \multicolumn{1}{c}{ Sig. } \\
\hline Between Groups & 2030.095 & 2 & 1015.047 & 32.340 & .000 \\
Within Groups & 3295.572 & 105 & 31.386 & & \\
Total & 5325.667 & 107 & & & \\
\hline
\end{tabular}

Table 3 shows that the significance is $0,000<0.05$, then $\mathrm{Ho}$ is rejected and $\mathrm{Ha}$ is accepted. It means that there is an influence of the age level on the Self-regulation of students.

Table 4. Length of study in Islamic Boarding Schools.

\begin{tabular}{lrrrrr}
\hline \multicolumn{1}{c}{ Source } & Sum of Squares & df & Mean Square & F & \multicolumn{1}{r}{ Sig. } \\
\hline Between Groups & 1438.936 & 2 & 719.468 & 19.436 & .000 \\
Within Groups & 3886.731 & 105 & 37.016 & & \\
Total & 5325.667 & 107 & & & \\
\hline
\end{tabular}

Table 4 shows that the significance of $0.000<0.05$, Ho is rejected, and Ha is accepted. It means that there is an influence of the length of study in the Islamic boarding school on students' self-regulation.

Table 5. Formal education.

\begin{tabular}{lrrrrr}
\hline \multicolumn{1}{c}{ Source } & Sum of Squares & Df & Mean Square & F & \multicolumn{1}{c}{ Sig. } \\
\hline Between Groups & 1947.609 & 2 & 973.805 & 30.269 & .000 \\
Within Groups & 3378.057 & 105 & 32.172 & & \\
Total & 5325.667 & 107 & & & \\
\hline
\end{tabular}

Table 5 shows that the significance is $0,000<0.05$, then Ho is rejected and $\mathrm{Ha}$ is accepted. It means that there is an influence of Formal Education on the students' selfregulation.

Table 6. Parental education.

\begin{tabular}{lrrrrr}
\hline \multicolumn{1}{c}{ Source } & Sum of Squares & df & Mean Square & F & \multicolumn{1}{c}{ Sig. } \\
\hline Between Groups & 562.207 & 3 & 187.402 & 4.092 & .009 \\
Within Groups & 4763.459 & 104 & 45.802 & & \\
Total & 5325.667 & 107 & & & \\
\hline
\end{tabular}

Table 6 shows that significance is $0.009<0.05$, then Ho is rejected and Ha is accepted. It means that there is an influence of parental education on students' self-regulation. 
Table 7. Previous education.

\begin{tabular}{|c|c|c|c|c|c|c|c|c|c|}
\hline \multirow[b]{2}{*}{ SRL } & \multirow[b]{2}{*}{ F } & \multirow[b]{2}{*}{ Sig. } & \multirow[b]{2}{*}{$T$} & \multirow[b]{2}{*}{ df } & \multirow{2}{*}{$\begin{array}{l}\text { Sig. (2- } \\
\text { tailed) }\end{array}$} & \multirow{2}{*}{$\begin{array}{c}\text { Mean } \\
\text { Difference }\end{array}$} & \multirow{2}{*}{$\begin{array}{c}\text { Std. Error } \\
\text { Difference }\end{array}$} & \multicolumn{2}{|c|}{$\begin{array}{l}\text { 95\% Confidence } \\
\text { Interval of the } \\
\text { Difference }\end{array}$} \\
\hline & & & & & & & & Lower & Upper \\
\hline $\begin{array}{l}\text { Equal variances } \\
\text { assumed }\end{array}$ & .089 & .766 & -.998 & 106 & .321 & -1.390 & 1.393 & -4.151 & 1.371 \\
\hline $\begin{array}{l}\text { Equal variances } \\
\text { not assumed }\end{array}$ & & & -1.007 & 90.078 & .317 & -1.390 & 1.380 & -4.131 & 1.352 \\
\hline
\end{tabular}

Table 7 shows that the results of previous education measurements found significant results of $0.766>0.05$ then $\mathrm{Ho}$ is accepted and $\mathrm{Ha}$ is rejected. It means that there is no effect of previous education on the Self-regulation of students.

Table 8. Students' place of origin.

\begin{tabular}{lrrrrr}
\hline & Sum of Squares & Df & Mean Square & F & \multicolumn{1}{c}{ Sig. } \\
\hline Between Groups & 146.806 & 2 & 73.403 & 1.488 & .230 \\
Within Groups & 5178.860 & 105 & 49.322 & & \\
Total & 5325.667 & 107 & & & \\
\hline
\end{tabular}

Table 8 shows that the significance of $0.230>0.05$ then Ho is accepted and Ha is rejected, meaning that there is no influence of the student's place of origin on the student's self-regulation. This study aims to identify factors that influence students' selfregulation seen from the background of student demographics in terms of gender, age, Length of study in Islamic Boarding Schools, formal education, parental education, previous education and students' place of origin. In this case learning is influenced by external and internal factors of students. First, gender is a factor that influences students' self-regulation. In this study, it was found that there was an influence on the level of self-regulation of students based on sex. Statistically significant differences in female students (Summary, 2014). Variants in the performance of female students and a large number of variances in male student achievement(Dabbagh \& Khajehpour, 2011). The Gender of students predicting independent learning strategies (Bozpolat, 2016). Thus, gender differences affect self-regulation of students.

Second is age, which influences students' ways of thinking (Cahan \& Cohen, 1989) and is related to performance (Mutangi, 2016). It means that the higher the age level of students, the higher the level of thinking. It is certainly synchronous with the selfregulated learning process, which requires thinking maturity for students. It is based on the results of research that shows the student age variable has a significant influence on students' self-regulation. Third, the length of study in boarding schools is one of the factors that influence the self-regulation of students, assuming that the improvement in student performance is influenced by staying in a dorm (Iftikhar \& Ajmal, 2015). It is based on the results of research that shows the variable length of study in Islamic boarding schools significantly influences students' self-regulation. Fourth, the level of formal education is one of the factors that distinguish students 'abilities in students' self regulations. In this study, it was found that there was an influence on the level of formal education on student self-regulation so that the higher levels of education obtain higher learning motivation (Irdianto \& Putra, 2016).

Fifth, Parental Education is one of the external factors closest to students, so parental involvement greatly affects students (Mcneal, 2014). It is certainly based on the level of 
Parental Education, which is an element of the influences (Farooq \& Berhanu, 2011). Highly educated parents may help learn self-regulation behaviors (Orange \& Hodges, 2015) through parenting styles in key aspects of SRL (Alnafea \& Curtis, 2017). In fact, students are encouraged to take college preparatory courses by increasing access to lecture objectives and their knowledge of the planning process in universities (Gregory \& Huang, 2013). Therefore, Parents' educational background may direct their children's learning methods according to their respective characteristics so that naturally highly educated parents has a large influence on the intensity of student learning. Thus, the self-regulation of students will be determined by parental education. So that the higher the level of Parental Education, the better the self-regulation of students. The findings are based on the findings that parental education is varied, from elementary to university level, so the results of this study indicate that the level of education of parents is very influential on students' self-regulations.

Sixth, Previous education is the initial construct for further education. Educational background influences the strength of motivation (Kusurkar et al., 2010). But in this study, there was no effect of previous education on student self-regulation. Seventh, the Students' place of origin is one of the factors that support the self-regulation of students. But in this study, this factor does not influences self-regulation in learning. Students from urban areas have more social skills awareness than students in rural areas (Akbar \& Davari, 2015). The lack of opportunities for rural students to interact with people from various backgrounds can be a limiting factor in the development of education.

The findings of this study prove that the dimensions of students backgrounds have a significant influence on students' self-regulation. Individuals as groups create progress in mutual understanding and learning (Miyake \& Kirschner, 2014), and group interactions have learning or knowledge that building effects (Cress, Stahl, Ludvigsen, $\&$ Law, 2015). In the same way, there are many variations in the implementation of learning. For example, teachers place different students in different groups, allowing students to work alone rather than in group settings (Barbara et al., 2012). The most basic source of motivation for teachers is their desire to be a success (Börü, 2018), Because the learning process consists of interrelated components, among others; graduation targets regarding quality and quantity, curriculum, learning management (Jaeni et al., 2020).

\section{CONCLUSIONS}

Self-regulated learning is a combination of academic learning skills and self-regulation that makes learning easier, it is due to many problems such as failure of students to achieve brilliant learning achievements, students of boarding schools feeling frustrated with the duties of the dormitory and school, and the density of time for learning, so that it requires new learning strategy that must be initiated and directed by the students themselves. In self-regulated learning, there are many factors underlying the success of students in implementing self-regulated learning strategies. These factors include gender, age, Length of study in Islamic Boarding Schools, formal education, Parental Education, and previous education have an influence on students' self-regulation. Partially Gender, Age, Length of Study in Islamic Boarding Schools, Formal Education, and Parental Education have a positive and significant effect on students' selfregulation. The implication of this study is that the number of factors that influence selfregulation must at least be the reference of the teachers. Further research is needed to 
test the practicality and effectiveness of self-regulated learning strategies to improve student learning skills either independently or in groups. There are a number of factors that we identified in this study and would benefit from further research, including a more realistic factor analysis to expand and further test the theory we have developed here. We recommend further studies for deeper examination and analysis of these factors, so that the next research

\section{REFERENCES}

Ajai, J. (2013). Urban and rural students' academic achievement and interest in geometry: A Case-study with games and simulations method. Taraba State University Journal of Education Research and Production, 1(2), 56-63.

Akbar, A., \& Davari, R. (2015). The comparison of life skills in male and female students of village and city in Chaharmahal and Bakhtiari Province. International Academic Institute for Science and Technology, 2(7), 21-27.

Alnafea, T., \& Curtis, D. D. (2017). Influence of mothers' parenting styles on self-regulated academic learning among Saudi primary school students Self-regulated learning. Issues in Educational Research, 27(3), 399-416.

Alokan, F. B., \& Arijesuyo, A. E. (2013). Rural and urban differential in student's academic performance among secondary school students in Ondo State, Nigeria. Journal of Educational and Social Research, 3(3), 213-218. https://doi.org/10.5901/jesr.2013.v4n3p213

Aminah, M. (2018). The effect of metacognitive teaching and mathematical prior knowledge on mathematical logical thinking ability and self-regulated learning. International Journal of Instruction, 11(3), 45-62.

Amro, H. J., \& Kupczynski, L. (2015). The effects of age and gender on student achievement in face-to- face and online college algebra classes. Research in Higher Education Journal, 27(1), $1-22$.

Barbara, S. W. B. P., Laura, L., Mcdonald, C., Doris, C., \& Marinak, B. (2012). Differentiated Instruction: Making Informed Teacher Decisions. The Reading Teacher, 66(4), 303-314. https:/ / doi.org/10.1002/TRTR.01126

Biedinger, N. (2011). The Influence of education and home environment on the cognitive outcomes of preschool children in Germany. Child Development Research, 2011, 1-10. https://doi.org/10.1155/2011/916303

Börü, N. (2018). The factors affecting teacher-motivation. International Journal of Instruction, 11(4), 761-776.

Bozpolat, E. (2016). Investigation of the self-regulated learning strategies of students from the faculty of education using ordinal logistic regression analysis. Kuram Ve Uygulamada Eğitim Bilimleri Educational Sciences: Theory \& Practice, 16(1), 301-318. https://doi.org/10.12738/estp.2016.1.0281

Cahan, S., \& Cohen, N. (1989). Age versus schooling effects on intelligence development. Child Development, 60(5), 1239-1249. https://doi.org/10.1111/j.1467-8624.1989.tb03554.x

Cobb, R. (2003). The Relationship Between Self-Regulated Learning and Academic Performance in WebBased Courses. Blacksburg, Virginia. Retrieved from https://vtechworks.lib.vt.edu/handle/10919/26469

Cress, U., Stahl, G., Ludvigsen, S. R., \& Law, N. (2015). The core features of CSCL: Social situation, collaborative knowledge processes and their design. International Journal of Computer-Supported Collaborative Learning, 10(2), 109-116. https://doi.org/10.1007/s11412015-9214-2

Dabbagh, S., \& Khajehpour, M. (2011). Gender differences in factors affecting academic performance of high school students. Procedia - Social and Behavioral Sciences, 15, 1040-1045. https://doi.org/10.1016/j.sbspro.2011.03.236

Dent, A. L., \& Koenka, A. C. (2016). The Relation between self-regulated learning and academic 
achievement across childhood and adolescence: A meta-analysis. Educational Psychology Review, 28(3), 425-474. https://doi.org/10.1007/s10648-015-9320-8

Ergen, B., \& Kanadli, S. (2017). The effect of self-regulated learning strategies on academic achievement: A meta-analysis study. Eurasian Journal of Educational Research, 69(69), 55-74. https://doi.org/10.14689/ejer.2017.69.4

Farooq, M. S., \& Berhanu, G. (2011). Factors affecting students' quality of academic performance: A case of secondary school level students'. Journal of Quality and Technology Management, VII(July 2016), 01-14.

Fatmawati, E. (2018). Integration of islamic boarding school and university: Typology study and curriculum of university student islamic boarding school. International Journal of Management and Administrative Sciences (IJMAS), 5(10), 1-17.

Fawait, A. (2013). Transformasi pengembangan tradisi pondok pesantren. Edu Islamika, 5(1), 93122.

Fawait, A. (2017). Life-based learning dengan menggunakan pendekatan living value instruction dalam tradisi akademik pesantren. ANCOMS 2017, 110, 698-707

Fawait, A. (2016). Reinventing kitab kuning sebagai warisan keilmuan islam nusantara. Islamic Akademika, 8(1), 1-16.

Fawait, A. (2017). Pendidikan pesantren: Sebagai suksesi life long education di Indonesia. Vicratina, 1(2), 53-60.

Gregory, A., \& Huang, F. (2013). It takes a village: The Effects of 10th grade college-going expectations of students, parents, and teachers four years later. American Journal of Community Psychology, 41-55. https://doi.org/10.1007/s10464-013-9575-5

Okere, M. (2013). Influence of school characteristics on the achievement of secondary school chemistry students in the cognitive science process skill of evaluation in Kenya. European Journal of Educational Research, 2(4), 171-183. https://doi.org/10.12973/eu-jer.2.4.171

Iftikhar, A., \& Ajmal, A. (2015). A qualitative study investigating the impact of hostel life. International Journal of Emergency Mental Health and Human Resilience, 17(2), 511-515.

Irdianto, W., \& Putra, A. B. N. R. (2016). The influence of education and economic background towards the training participants' motivation and study result of UPT-PK Singosari Malang. AIP Conference Proceedings, 1778.

Isohätälä, J., Järvenoja, H., \& Järvelä, S. (2017). Socially shared regulation of learning and participation in social interaction in collaborative learning. International Journal of Educational Research, 81, 11-24. https://doi.org/10.1016/j.ijer.2016.10.006

Jabor, M. K. (2011). The influence of age and gender on the students' achievement in mathematics. International Conference on Social Science and Humanity, 5, 304-308.

Jaeni, U., Basuki, I., \& Moedjiarto. (2020). Culture learning management Al-Quran model tilawati to improve student character. IJORER: International Journal of Recent Educational Research, 1(3), 286-300. https:/ / doi.org/10.46245/ijorer.v1i3.65

Jannah, M., ZA Imam, S., \& Prabowo. (2020). Guided inquiry model with the REACT strategy learning materials to improve the students' learning achievement. IJORER: International Journal of Recent Educational Research, 1(2), 156-168. https:/ / doi.org/10.46245/ijorer.v1i2.45

Järvelä, S., Kirschner, P. A., Hadwin, A., Järvenoja, H., Malmberg, J., Miller, M., \& Laru, J. (2016). Socially shared regulation of learning in CSCL: Understanding and prompting individual- and group-level shared regulatory activities. International Journal of ComputerSupported Collaborative Learning, 11(3), 263-280. https:/ / doi.org/10.1007/s11412-016-9238-2

Kainuwa, A., \& Yusuf, N. B. M. (2013). Influence of socio-economic and educational background of parents on their children's education in Nigeria. International Journal of Scientific and Research Publications, 3(10), 1-8.

Kastur, A., Mustaji, \& Yatim, R. (2020). Feasibility of developing direct learning models with a life based learning approach. IJORER: International Journal of Recent Educational Research, 1(3), 261-270. https://doi.org/10.46245/ijorer.v1i3.63 
Kusurkar, R., Kruitwagen, C., \& Croiset, G. (2010). Effects of age, gender and educational background on strength of motivation for medical school. Advance in Health Science Education, 303-313. https://doi.org/10.1007/s10459-009-9198-7

Ma'arif, S. (2018). Education as a foundation of humanity: Learning from the pedagogy of pesantren in Indonesia. Journal of Social Studies Education Research, 9(2), 104-123.

Manafe, Y. Y., Setyosari, P., Kuswandi, D., \& Ulfa, S. (2016). Pengaruh Strategi kerjasama kelompok dan efikasi diri terhadap hasil belajar keterampilan teknikal. Jurnal Pendidikan Humaniora, 4(3), 152-162.

Mcneal, R. B. (2014). Parent involvement, academic achievement and the role of student attitudes and behaviors as mediators. Universal Journal of Educational Research, 2(8), 564576. https://doi.org/10.13189/ujer.2014.020805

Miyake, N., \& Kirschner, P. A. (2014). The social and interactive dimensions of collaborative learning. The Cambridge Handbook of the Learning Sciences, Second Edition, 418-438. https://doi.org/10.1017/CBO9781139519526.026

Mutangi, K. (2016). Understanding Factors Affecting Performance in an Elementary Biostatistics Course at Harare Institute of Technology. American Journal of Educational Research, 4(6), 479-483. https://doi.org/10.12691/education-4-6-6

Ningsih, S. K., Narahara, S., \& Mulyono, H. (2018). An Exploration of factors contributing to students' unwillingness to communicate in a foreign language across indonesian secondary schools. International Journal of Instruction, 11(4), 811-824. https://doi.org/10.12973/iji.2018.11451a

Orange, C., \& Hodges, T. L. (2015). Influence of self-regulated learning and parental education on post-secondary remediation. Journal of Instructional Pedagogies, 16, 1-21.

Pantiwati, Y. (2017). Self and Peer Assessments in Active Learning Model to Increase Metacognitive Awareness and Cognitive Abilities. International Journal of Instruction, 10(4), 185-202. Retrieved from www.e-iji.net

Phan, H. P. (2011). Interrelations between self-efficacy and learning approaches: A developmental approach. Educational Psychology, 31(2), 225-246. https://doi.org/10.1080/01443410.2010.545050

Priyono. (2018). The Implementation of PAIKEM (Active, Innovative, Creative, Effective, and Exiting Learning) and conventional learning method to improve student learning results. Journal of Social Studies Education Research, 9(2), 124-137.

Ratminingsih, N. M., Artini, L. P., \& Nyoman, P. (2017). Incorporating Self and peer assessment in reflective teaching practices. International Journal of Instruction, 10(4), 165-184.

Reigeluth, Charles M., \& Carr-Chellman, A. (2009). Instructional-design theories and models: Building a common knowledge base. New York: Routledge.

Roslan, M., Nor, M., \& Malim, M. (2014). Revisiting Islamic education : The case of Indonesia. Journal for Multicultural Education, 8(4), 261-276. https://doi.org/10.1108/JME-05-20140019

Suardi, I. (2015). Arabic teaching and learning: A model from Indonesian Muslim Minority. Procedia - Social and Behavioral Sciences, 191, 286-290. https://doi.org/10.1016/j.sbspro.2015.04.236

Suardi, I., \& Hamid, S. (2013). Technology on language teaching and learning: A research on Indonesian Pesantren. Procedia - Social and Behavioral Sciences, 83, 585-589. https://doi.org/10.1016/j.sbspro.2013.06.111

Summary, E. (2014). Investigation of self-regulation and problem solving skills of prospective elementary teachers 1. International Online Journal of Educational Sciences, 6(2), 413-428. https://doi.org/http://dx.doi.org/10.15345/iojes.2014.02.014 (

Ucan, S., \& Webb, M. (2015). Social regulation of learning during collaborative inquiry learning in science: How does it emerge and what are its functions? International Journal of Science Education, 37(15), 2503-2532. https://doi.org/10.1080/09500693.2015.1083634 
Vrieling, E. M., Bastiaens, T. J., \& Stijnen, P. J. J. (2013). The "self-regulated learning opportunities questionnaire": A diagnostic instrument for teacher educators' professional development. Professional Development in Education, 39(5), 799-821. https://doi.org/10.1080/19415257.2012.708905

Winarko, B. (2007). Content, benefits and development of pesantren online in Indonesia. Malaysian Journal of Library \& Information, 12(2), 57-75.

Yates, J., Smith, J., James, D., \& Ferguson, E. (2009). Should applicants to Nottingham University Medical School study a non-science A-level? A cohort study. BMC Medical Education, 9, 19. https://doi.org/10.1186/1472-6920-9-5

Yeyeng, A. T. (2017). ICMI And education: An effort to prepare muslim intellectuals in Indonesia. Journal of Islamic Civilization in Southeast Asia (JICSA), 06(02), 413-430.

Yildirim, B., \& Ozkahraman, S. (2011). Critical thinking in nursing process and education. International Journal of Humanities and Social Science, 1(13), 257-262.

Yusuf, M., \& Suardi, I. (2015). Active Learning on teaching arabic for special purpose in Indonesian Pesantren. Procedia - Social and Behavioral Sciences, 191, 137-141. https://doi.org/10.1016/j.sbspro.2015.04.245

\footnotetext{
${ }^{*}$ Agus Fawait (Corresponding Author)

Department of Islamic Education, STAI At-Taqwa Bondowoso,

Jl. Hoscokroaminoto, Kademangan Bondowoso, East Java, 68217, Indonesia

Email: agusfawaid87@gmail.com

\section{Safaruddin}

Department of Islamic Education, IAIM Sinjai,

Jl. Sultan Hasanudin No.20, Balangnipa, Sinjai Utara, Kabupaten Sinjai, 92614 Indonesia

Email: sarthi339@gmail.com
} 